\title{
Jornalismo e Literatura: um encontro para (des)encontrar
}

Somos aprendizes duma arte que ninguém nunca domina.

Hemingway

Literatura - Jornalismo - Jornalismo Literário - são três temas que, em conjunto, ganharam em Portugal espaço de grande debate depois da criação de Escolas de Jornalismo, ou seja, após a Revolução de 25 de Abril de 1974, isto apesar de o País ser centenário em universidades e em jornais diários; a cidade do Porto, por exemplo, foi até Junho de 2005, e durante décadas, uma das poucas cidades europeias a dispor de três jornais diários centenários: 0 Comércio do Porto, o Primeiro de Janeiro e o Jornal de Notícias.

O debate tem-se intensificado e ganha contornos de grande actualidade; não é consensual, o que por si só é positivo, mas corre sérios riscos de chegar a um ponto de confusão instalada sem retorno, para o que contribuem de forma preocupante determinadas plataformas nas redes sociais, alimentadas por overdoses de informação sem a supervisão do conhecimento ou o filtro da experiência.

É o desenvolvimento social a seguir o seu rumo sem cuidar do que é essencial nesta matéria: a separação do que é Literatura e Jornalismo, que são dois modos distintos de narrar usando a palavra como instrumento comum.

Pode um jornalista ser escritor? Sim.

Pode um escritor ser jornalista? Sim.

O que os distingue é a forma de utilizar a linguagem. No jornalismo, enquanto informação rigorosa, não há lugar para a fiç̧ão; pauta-se pela veracidade dos factos e pelo rigor nas entrevistas e nas reportagens. Não se deve usar a riqueza da linguagem literária para, com os seus estilos, embelezar a tragédia ou distorcer qualquer realidade. 0 jornalismo assenta na objectividade: todo o jornalismo, do generalista ao especializado. É isso o que os leitores procuram quando compram um jornal: informação em que possam acreditar. E aqui o jornalismo cultural ou literário não é excepção, até porque só existe um código deontológico para os jornalistas, que abrange todas as áreas, da desportiva à económica, da política à cultural.

A colaboração de escritores nos jornais é secular, foi e é vital para a diversidade e qualidade dos seus conteúdos. São famosas as crónicas de Paris de Eça, publicadas em finais do século XIX no Primeiro de Janeiro, bem como as que durante anos assinou na revista Visão António 
Lobo Antunes, finais do século XX e início deste século, como ainda hoje são lembradas As Farpas, essas deliciosas prosas protagonizadas por Ramalho Ortigão e Eça e publicadas periodicamente durante mais de um ano, igualmente no Primeiro de Janeiro.

Os jornais generalistas portugueses durante mais de 40 anos publicaram suplementos culturais semanais, que foram dirigidos por poetas e escritores: Alberto Serpa no Primeiro de Janeiro e Costa Barreto no Comércio do Porto. Páginas muitas delas polémicas na arte da escrita e na escrita da arte e cujos responsáveis faziam questão de se afirmar como "livres pensadores" e rigorosos "escritores".

Agustina Bessa-Luís, quando em meados de 1986 assumiu a direcção de 0 Primeiro de Janeiro, tornando-se assim a primeira mulher em Portugal a dirigir um jornal diário, afirmou de imediato que era escritora e não jornalista, o que não a impediria (como não impediu) de escrever os editoriais ao seu melhor estilo: "em bom português" e a criticar os usos e costumes sem medo nem preconceito, com sentido de humor fino e felino.

Aqui deixo um exemplo de um dos seus editoriais (de O Primeiro de Janeiro, 1986).

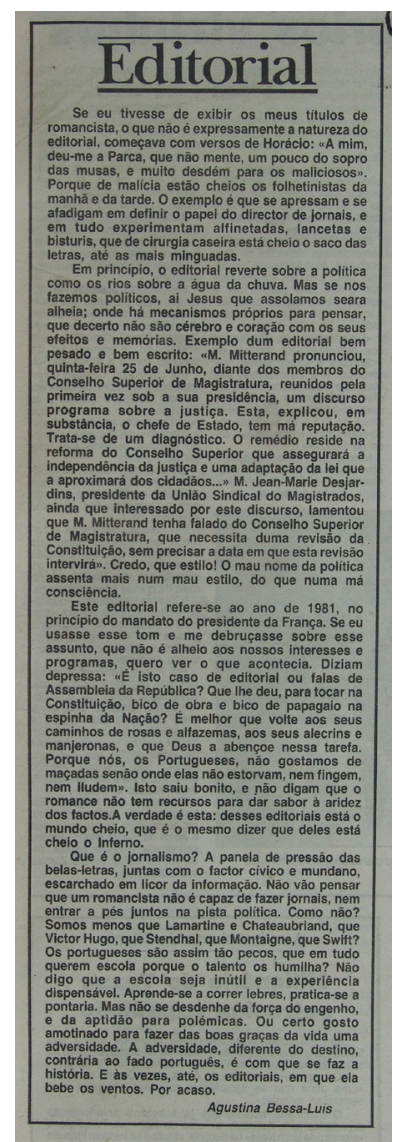


Não seria de esperar outra coisa desta directora/escritora. E foi assim durante um ano, com o jornal a seguir o seu caminho informativo nas páginas seguintes com as reportagens, entrevistas, casos do dia, da polícia, do desporto, de economia, do País e do mundo. O mesmo jornal que semanalmente inseria o suplemento literário "Das Artes Das Letras"

A propósito de jornalismo cultural em geral e literário em particular, Agustina Bessa-Luís, costumava dizer que o essencial era escrever bem, dominar a língua, usar o dicionário e dizer não ao que "não presta". Tinha a certeza de que nem todos os livros mereciam ser divulgados, nem todos os artistas apresentados; isto no criterioso respeito "pela sanidade" dos leitores.

E fiç̧ão nas páginas culturais?

"Sim, se escritas por escritores ou jornalistas que saibam contar bem uma estória...".

É o que acontece semanalmente nos dias de hoje na revista Visão, com os escritores Mia Couto, Eduardo Agualusa e Dulce Maria Cardoso, a escreverem os seus contos.

Nada de novo, porquanto até contos de Camilo Castelo Branco, entre outros escritores, foram publicados em pequenos episódios em jornais portuenses.

Mas estão bem definidas as características de um texto literário e de um texto jornalístico. Um livro não é uma revista ou um jornal. Um romance sobre a tragédia que envolve a pandemia causada pela Covid 19 não é o mesmo que as notícias diárias das mortes, dos hospitalizados e da falta de meios registados para os tratar. Não há poesia na descrição de um doente que morre numa ambulância à porta de um hospital por falta de tratamento, mesmo que a morte seja a de um poeta! Mas essa mesma morte pode ser o princípio de um poema, pode ser o último suspiro do personagem principal de um conto, novela ou romance. Pode inspirar pintores, dramaturgos e cineastas. A diferença não está no uso da palavra mas sim na forma como é feita a narrativa.

A imaginação, a capacidade de significar, o jogo entre os valores do significado e do significante cabem ao texto literário, que no jornalismo abrangem os editoriais, as crónicas e os artigos de opinião. A descrição da realidade e da verdade, o testemunho dos factos e o respeito pelas fontes, são a base das notícias, a razão de ser da informação e as regras fundamentais do jornalismo. Também do jornalismo cultural.

Jornalismo e Literatura não são antagónicos. Antes caminham lado a lado. Contam estórias e fazem História. Nem tudo o que ficcional é literatura como nem tudo o que apresentado como verdadeiro e real é jornalismo. Os géneros, sendo distintos, coabitam e hoje em dia até se confundem vezes sem conta. Ambos têm o público como objectivo; ambos almejam influenciar os leitores (em maior ou menor número), seduzi-los para a sua narrativa e fidelizá-los. Os escritores podem dar-se ao luxo de escolher os seus nichos, as suas minorias; os jornalistas ambicionam as maiorias, projectam o seu trabalho para atingir todas as franjas sociais, sabendo bem quão efémero é o seu resultado do seu labor! A lógica comunicacional dos escritores e dos jornalistas não é a mesma. A satisfação da necessidade de informação está nos jornais. A do conhecimento, nos livros.

Baptista-Bastos defendia que o jornalismo "é uma disciplina superior da literatura". Não se referia ao jornalismo cultural ou literário, apenas ao jornalismo como área de investigação, de divulgação do saber e de meio de comunicação privilegiado com as multidões. 
Em tempos em que a ciberliteratura está a criar o seu espaço e o ciberjornalismo já se sedimentou, urge não perder o foco do essencial: o respeito pela capacidade crítica dos leitores e pela sua liberdade de escolha. Afinal é o público que tem o poder de decidir a vida dos livros e dos jornais e os escritores e os jornalistas são apenas os artífices da palavra. São mediadores comunicacionais a interagirem de forma mais ou menos peneirada. Para os escritores a ficção, a interpretação livre do que se passa ao fundo da sua rua, na aldeia vizinha, no mundo real ou imaginário, o primado da especulação, da ilusão e da fantasia, o olhar límpido ou turvo sobre o pulsar da sociedade, da sua evolução, da sua decadência. Os jornalistas não podem inventar casos, não devem mentir sobre os factos nem especular sobre boatos.

A todos, é devida a estética nas formas e a ética nos conteúdos.

NOTA

* Maria de Nassalete Guedes Diz (Nassalete Miranda é nome profissional) é licenciada em Filologia Germânica pela Universidade do Porto e fez uma pós-graduação em Direito da Comunicação, na Faculdade de Direito da Universidade de Coimbra. Docente do ensino secundário e do ensino superior, foi chefe de redação da Rádio Comercial, chefe de serviços de informação na RDP e diretora de 0 Primeiro de Janeiro. Desde 2009, é fundadora e directora do jornal cultural quinzenal As Artes entre As Letras e, desde 2021, membro efectivo do Conselho de Opinião da RTP. Tamném é Membro do Conselho estratégico da Universidade Lusófona. Recebeu a Medalha de Mérito, grau ouro da Cidade do Porto. 